\title{
Effect of casein to whey protein ratios on the protein interactions and coagulation properties of low-fat yogurt
}

\author{
L. L. Zhao, ${ }^{*} \dagger^{1}$ X. L. Wang, ${ }^{* 1}$ Q. Tian, $\dagger$ and X. Y. Mao* ${ }^{*}$ \\ *Beijing Advanced Innovation Center for Food Nutrition and Human Health, College of Food Science and Nutritional Engineering, \\ China Agricultural University, Beijing 100083, China \\ †Key Laboratory of Functional Dairy, Ministry of Education, College of Food Science and Nutritional Engineering, China Agricultural University, \\ Beijing 100083, China
}

\begin{abstract}
In this study, we investigated the effect of casein $(\mathrm{CN})$ to whey protein (WP) ratios $(4: 1,3: 1,2: 1$, and $1: 1)$ on gelation properties and microstructure of low-fat yogurt made with reconstituted skim milk with or without addition of whey protein concentrate. The rheological properties (storage modulus, $\mathrm{G}^{\prime}$; yield stress; and yield strain) of the obtained low-fat yogurt were greatly enhanced, the fermentation period was shortened, and the microstructure became more compact with smaller pores as the CN:WP ratio decreased. When CN:WP was $2: 1$ or $1: 1$, the obtained yogurt coagulum showed higher $\mathrm{G}^{\prime}$ and greater yield stress, with more compact crosslinking and smaller pores. In addition, the more of skim milk powder was replaced by whey protein concentrate, the more disulfide bonds were formed and the greater the occurrence of hydrophobic interactions during heat treatment, which can improve the rheological properties and microstructure of low-fat yogurt.
\end{abstract}

Key words: casein to whey protein ratio, low-fat yogurt, rheological behavior, microstructure

\section{INTRODUCTION}

Low-fat yogurt has been attracting increasing attention from health-conscious consumers because of its nutritional values and health-promoting properties (Kücükcetin, 2008). However, milk fat has important roles in emulsification and in flavor and texture development in the formed gels. A reduced fat content may reduce viscosity and increase whey syneresis, which can affect the appearance, texture, and mouthfeel of lowfat yogurt (Lee and Lucey, 2004; Houzé et al., 2005). Therefore, improving the structure and flavor deficiencies of low-fat yogurt deserves close attention.

Received December 22, 2015.

Accepted March 24, 2016.

${ }^{1}$ These authors contributed equally to this research.

${ }^{2}$ Corresponding author: maoxueying@cau.edu.cn
Several methods have been used to improve the properties of low-fat yogurt, including addition of whey protein (WP), use of suitable starter cultures, enhanced total solids content, use of thickeners, and modification of processing parameters (Sodini et al., 2004). The viscoelasticity or apparent viscosity of yogurt can be increased 2 to 3 times by adjusting the total solids and protein contents or by adding thickeners or enzymes to the milk base. Addition of thickeners (polysaccharides or gelatin) or enzymes (lactoperoxidase, protease, and transglutaminase) allows for new cross-links in the network and enhances the rigidity of the gel and its waterholding capacity. Processing parameters, including heat treatment, shearing, homogenization, and storage period, affect texture and thickness-in-mouth of yogurt. Starter cultures help to improve the smoothness and water-holding capacity of yogurt, because they can produce exopolysaccharides (EPS) during fermentation and gel formation. The addition of increasing levels of $\beta$-LG causes marked increases in storage modulus $\left(\mathbf{G}^{\prime}\right)$ compared with $\alpha$-LA, and some differences in behavior exist among the different $\beta$-LG variants (GravelandBikker and Anema, 2003).

Heat treatment, one of the predominant processes of dairy product manufacturing, leads to denaturation of milk proteins and interaction among denatured milk proteins, which may dramatically affect the texture and consistency of yogurt (Mulvihill and Grufferty, 1995). Whey proteins are much more heat-sensitive than casein. The denatured WP interact with each other to form soluble WP aggregates or interact with casein micelles to form WP-coated casein micelles (Krzeminski et al., 2011). Most WP are denatured during normal heat treatment of yogurt manufacture, during which the formation of disulfide bonds and occurrence of hydrophobic interactions within denatured WP and between denatured WP and $\kappa-\mathrm{CN}$ on the surface of casein micelles leads to the formation of $\mathrm{WP}-\kappa$-casein complexes (Smits and Brouwershaven, 1980; Haque and Kinsella, 1988; Singh and Myhr, 1998). Addition of WP has potential application in the manufacture of yogurt 
(Lucey et al., 1999; Graveland-Bikker and Anema 2003), cheese (Hinrichs, 2001; Kelly and O'Kennedy, 2001), and other coagulated dairy products; it not only improves physical properties and microstructure but also alters the functional properties of the obtained products. Therefore, heat treatment of milk fortified with WP is conducive to a high level of crosslinking within the gel network, which results in a denser yogurt structure and enhanced yogurt viscosity and waterholding capacity (Remeuf et al., 2003).

Although WP fortification has been investigated in the processing of low-fat yogurt, it is difficult to independently evaluate the effect of whey proteins on yogurt properties because the addition of WP also changes the protein and TS contents (Damin et al., 2009). Including a high proportion of WP might impart an undesirable whey flavor as well as a grainy texture under some conditions (Lucey and Singh, 1997; González-Martınez et al., 2002). In addition, a relatively low content of casein is believed to result in a more open gel structure, making the coagulum network more sensitive to syneresis (González-Martınez et al., 2002). Therefore, determining the proper ratio of CN to WP is critically important. Whey protein concentrate (WPC) had been used to partially substitute for skim milk powder (SMP) to alter the $\mathrm{CN}$ :WP ratio in yogurt manufacture (Bhullar et al., 2002; Akalin et al., 2008). By using a decreased CN:WP ratios, increased maximum gel strength, reduced whey drainage, and a denser network could be obtained (Puvanenthiran et al., 2002; Kücükcetin, 2008), and lower viscosity and higher intensities of graininess and yellow color would be also exhibited (Tomaschunas et al., 2012). Although some research has been conducted on $\mathrm{CN}$ :WP ratios in yogurt, the effects on the fermentation process and the interaction between $\mathrm{CN}$ and WP have not yet been investigated.

The objective of this research was to investigate the effect of $\mathrm{CN}$ :WP ratios with constant protein content on the gelation properties and microstructure of low-fat yogurt. The interactions within denatured whey protein

Table 1. The formula of milk base with different casein to whey protein ratios

\begin{tabular}{lcccc}
\hline & \multicolumn{5}{c}{ Casein to whey protein ratio } \\
\cline { 2 - 5 } Item $^{1}$ & $4: 1$ & $3: 1$ & $2: 1$ & $1: 1$ \\
\hline $\mathrm{SMP}(\mathrm{g} / 100 \mathrm{~mL})$ & 12.94 & 12.13 & 10.78 & 8.08 \\
$\mathrm{WPC}(\mathrm{g} / 100 \mathrm{~mL})$ & 0 & 0.33 & 0.87 & 1.96 \\
Total protein $(\%)$ & 4.0 & 4.0 & 4.0 & 4.0 \\
Total solids $(\%)$ & 12.94 & 12.46 & 11.65 & 10.04 \\
\hline
\end{tabular}

${ }^{1} \mathrm{SMP}=$ skim milk protein; $\mathrm{WPC}=$ whey protein concentrate. and casein micelles was also evaluated by determination of disulfide bonds and surface hydrophobicity. Samples with CN:WP ratios of $3: 1,2: 1$, and 1:1 were compared with a reference yogurt manufactured with skim milk powder with a $\mathrm{CN}$ :WP ratio of $4: 1$.

\section{MATERIALS AND METHODS}

\section{Materials and Chemicals}

Skim milk powder (by weight, $32.5 \%$ protein, $0.43 \%$ fat, $52.1 \%$ carbohydrates; $\mathrm{CN}: \mathrm{WP}=4: 1)$ and whey protein concentrate 80 (WPC80; by weight, $81.23 \%$ protein, $0.11 \%$ fat, $13.30 \%$ carbohydrates) were supplied by Hilmar Ingredients (Hilmar, CA). 8-Anilino1-naphthalenesulfonic acid (ANS) and 5,5'-dithio-bis2nitrobenzoic acid (DTNB) were obtained from Sigma Chemical Co. (St. Louis, MO). Other reagents used in the present study were of analytical grade.

\section{Preparation of Low-Fat Yogurt}

Milk Base Preparation. Control milk base was prepared as follows: $12.94 \mathrm{~g}$ of SMP was added to 87.06 $\mathrm{g}$ of distilled water at $25^{\circ} \mathrm{C}(\mathrm{CN}: \mathrm{WP}$ ratio $=4: 1)$. Experimental trials were prepared by mixing SMP with WPC80 quantitatively at CN:WP ratios of $3: 1,2: 1$, and 1:1, respectively, as shown in Table 1 . The total milk base content was $100 \mathrm{~g}$ and the protein content of all samples was $4 \%$ (wt/wt). The milk bases were stirred for $3 \mathrm{~h}$ at $25^{\circ} \mathrm{C}$ and stored at $4^{\circ} \mathrm{C}$ overnight to ensure complete hydration.

Fermentation. One hundred grams of each sample was prepared. After homogenization at $20 \mathrm{MPa}$ and $55^{\circ} \mathrm{C}$, each milk base was treated in a thermostatically controlled boiling water bath (DK-8B, Jinghong Laboratory Equipment Co. Ltd., Shanghai, China) until the center temperature of sample reached $95^{\circ} \mathrm{C}$ and was then held for $5 \mathrm{~min}$. The heated samples were immediately cooled to $42^{\circ} \mathrm{C}$ for analysis and further fermentation. Direct Vat Set starter culture (ABY-8, Chr. Hansen, Milwaukee, WI) containing Streptococcus thermophilus, Lactobacillus acidophilus, Lactobacillus delbrueckii ssp. bulgaricus, and Bifidobacterium was added at the recommended concentration of $0.005 \%$ (wt/wt). Milk samples were incubated at $42^{\circ} \mathrm{C}$, and the fermentation process was immediately stopped by rapidly cooling to $4^{\circ} \mathrm{C}$ in an ice-water bath until the $\mathrm{pH}$ value decreased to 4.60. The obtained yogurt samples were stored at $4^{\circ} \mathrm{C}$ for further measurements. The samples were prepared in triplicates and new preparation was made for each replicate. 


\section{Determination of Rheological Properties}

Yogurt gel formation process was monitored using a Universal Dynamic Spectrometer (AR1500ex, TA Instruments, New Castle, DE) with a top plate (diameter $60 \mathrm{~mm}$ ). Two-milliliter milk samples, which were inoculated with starter culture, were transferred to the bottom. A few drops of silicone oil were added to cover the edge of the plate to prevent evaporation during the measurements. The oscillation was set at a constant frequency of $1 \mathrm{~Hz}$ and a constant strain of $0.1 \%$, which caused minimal disruption during the development of gel network (Van Camp et al., 1997). Measuring points were taken every 1 min until $\mathrm{pH} 4.6$ was reached. Gelation time was defined as the moment when the $\mathrm{G}^{\prime}$ values of the obtained gels were greater than $1 \mathrm{~Pa}$ (Lucey et al., 1997). Fermentation time was the time for $\mathrm{pH}$ to reach 4.6. Two samples were prepared at the same time, one for monitoring $\mathrm{pH}$ and fermentation time and the other for determination of rheological properties.

The large-deformation properties of yogurt gels were determined by applying a single constant shear rate $\left(\sim 0.01 \mathrm{~s}^{-1}\right)$. The strain applied varied from 0.003 to $100 \%$. Yield stress $\left(\sigma_{\text {yield }}\right)$ was defined as the point when shear stress started to decrease, and yield strain $\left(\mathrm{y}_{\text {strain }}\right)$ was the strain value at the yield point (Lucey, 2002).

\section{Microstructure Measurement}

Confocal scanning laser microscopy was used to evaluate the microstructure of yogurt gels as reported by Lucey et al. (1998). Rhodamine B (Sigma Chemical Co.) was used as a fluorescent protein dye and dissolved in demineralized water to a concentration of 10 $\mathrm{mg} / \mathrm{mL}$. One milliliter of Rhodamine B solution and starter culture was added to $100 \mathrm{~g}$ of heat-treated milk and mixed using a magnetic stirrer (CJJ78-1, Jingke Scientific Instrument Co. Ltd., Shanghai, China) for 5 min. A few drops of each sample was transferred to a concave slide with a coverslip, which were then incubated at $42^{\circ} \mathrm{C}$ until the $\mathrm{pH}$ value reached 4.6. The endpoint of fermentation was judged using the remainder of the 100-g milk samples that were fermented at the same time. The obtained gel samples were observed using a Leica TCS 4D confocal microscope (Leica Lasertechnik GmbH, Heidelberg, Germany) with a $60 \times$ oil immersion objective (numerical aperture $=1.4$ ) at an excitation wavelength of $568 \mathrm{~nm}$. All experiments were done in triplicate. Many fields were viewed and typical micrographs are presented.

\section{Determination of Disulfide Bond Content}

Disulfide bond (-S-S-) contents of the samples were determined using Ellman's reagent according to the method described by Beveridge et al. (1974). First, $0.2 \mathrm{~mL}$ of heated or unheated milk dispersion was diluted with $1 \mathrm{~mL}$ of buffer $(0.086 M$ Tris, $0.09 M$ glycine, $4 \mathrm{~m} M$ EDTA, $10 M$ urea, $\mathrm{pH} 8.0$ ), $0.02 \mathrm{~mL}$ of $\beta$-mercaptoethanol, and $10 \mathrm{~mL}$ of $12 \%$ trichloroacetic acid (TCA); incubated for $1 \mathrm{~h}$ at $25^{\circ} \mathrm{C}$; and then centrifuged at $5,000 \times g$ for $15 \mathrm{~min}$. The precipitate was washed twice with $12 \%$ (wt/vol) TCA and centrifuged as described above. The obtained sediment was subsequently dissolved in $4 \mathrm{~mL}$ of standard buffer $(0.086 \mathrm{M}$ Tris, $0.09 M$ glycine, $4 \mathrm{~m} M$ EDTA, $\mathrm{pH} 8.0), 0.03 \mathrm{~mL}$ of Ellman's reagent was added, and the mixture was held for $10 \mathrm{~min}$, and the absorbance at $412 \mathrm{~nm}$ was measured by a spectrophotometer (UV-2600, Unico Instrument Co. Ltd., Shanghai, China). The disulfide bond content was calculated using a molar extinction coefficient of $13,600 \mathrm{M}^{-1} \cdot \mathrm{cm}^{-1}$ (Ellman, 1959) and expressed as micromoles per gram of protein.

\section{Determination of Surface Hydrophobicity}

Surface hydrophobicity was determined according to the method described by Alizadeh-Pasdar and LiChan (2000). Milk samples were diluted at 5 protein concentrations between 0.0025 and $0.0125 \%$ by addition of PBS (0.01 M, pH 7.0). Then, $40 \mu \mathrm{L}$ of $8 \mathrm{mM}$ ANS buffer was added to $4 \mathrm{~mL}$ of diluted milk dispersion. The relative fluorescence intensity of the samples was measured using a fluorescence spectrophotometer (model RF-5301PC, Shimadzu, Kyoto, Japan), with excitation and emission wavelength of 390 and 470 $\mathrm{nm}$, respectively. Samples without ANS addition were recorded as blanks. Surface hydrophobicity was calculated according to the slope method and expressed as the specific value of initial slope of the relative intensity and protein concentration.

\section{Statistical Analysis}

The experimental design was a single factor design and all experiments were carried out at least 3 times with 3 replicates in this study. Data are reported as means \pm standard deviations (SD). Analysis of significant difference and variance tests were performed by one-way ANOVA using SPSS software (version 13.0 for Windows; SPSS Inc., Chicago, IL). Differences were considered significant at $P<0.05$.

\section{RESULTS}

\section{Coagulation Properties of Low-Fat Yogurt Gels with Different CN:WP Ratios}

The rheological properties of low-fat yogurt fortified with different $\mathrm{CN}$ :WP ratios were observed in the for- 
mation process. The $\mathrm{G}^{\prime}$ profiles as a function of $\mathrm{pH}$ of yogurts are shown in Figure 1. When the $\mathrm{pH}$ value was $>5.83$, the $\mathrm{G}^{\prime}$ profiles of the yogurt samples were similar and close to zero. When $\mathrm{pH}$ values were between 5.76 and 5.27 , the $\mathrm{G}^{\prime}$ value of yogurt with $\mathrm{CN}$ :WP of 1:1 increased continuously, whereas profiles of the other 3 samples exhibited a shoulder. When $\mathrm{pH}$ was $<5.27$, the $G^{\prime}$ values of all samples increased until the end of fermentation process, whereas the rate of increase of $\mathrm{G}^{\prime}$ was the highest in yogurt with a CN:WP ratio of 1:1, which correspondingly had the highest $\mathrm{G}^{\prime}$ value at $\mathrm{pH}$ 4.6 .

\section{Rheological Properties of Low-Fat Yogurts with Different CN:WP Ratios}

Rheological properties of low-fat yogurt prepared at CN:WP ratios from 4:1 to 1:1 are presented in Table 2. The decrease in CN:WP ratios with constant total protein content considerably shortened the fermentation time and gelation time of yogurt. The $\mathrm{G}^{\prime}$ values at $\mathrm{pH} 4.6$ and $\mathrm{pH}$ values at gelation increased when the $\mathrm{CN}$ :WP ratio decreased. When the $\mathrm{CN}$ :WP ratio was $1: 1$, fermentation time and gelation time were the shortest, whereas the $\mathrm{pH}$ at gelation time point and $\mathrm{G}^{\prime}$ at $\mathrm{pH} 4.6$ were the highest.

The results of the large-deformation test are presented in Figure 2. A decrease in CN:WP ratio resulted in an increase in yield stress and strain of low-fat yogurt. The sample with a $\mathrm{CN}$ :WP of 1:1 had the highest yield stress and strain, $54 \mathrm{~Pa}$ and $42.81 \%$, respectively, whereas the sample with a CN:WP of $4: 1$ had the lowest yield stress and strain values, $4.2 \mathrm{~Pa}$ and $12.28 \%$, respectively.

\section{Microstructure of Low-Fat Yogurts with Different CN:WP Ratios}

The microstructures of low-fat yogurt gels with different $\mathrm{CN}$ :WP ratios were examined by confocal scanning laser microscopy as shown in Figure 3. At a CN:WP of $4: 1$, the low-fat yogurt showed a more interrupted structure with larger pores (diameter $\sim 20$

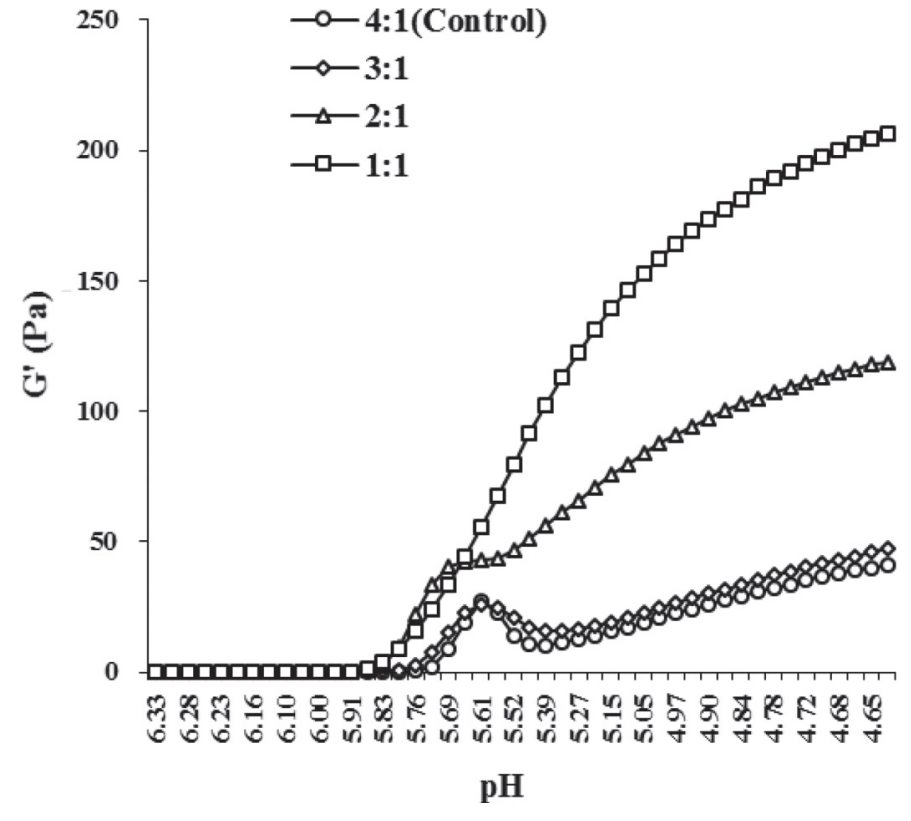

Figure 1. The change of storage modulus $\left(\mathrm{G}^{\prime}\right)$ as a function of $\mathrm{pH}$ for low-fat yogurts fortified with casein to whey protein ratios of $4: 1$ (control), 3:1, 2:1, and 1:1.

$\mu \mathrm{m}$; Figure 3A). As the CN:WP ratio decreased, the crosslinked network became denser and finer, and the pores became smaller, as shown in Figure 3B, C, D. The yogurt with a CN:WP of 1:1 (Figure 3D) appeared the most homogeneous, with the smallest and most evenly distributed pores.

\section{Effect of CN:WP and Temperature on Disulfide Bond Content and Surface Hydrophobicity}

The disulfide bond contents of samples are presented in Table 3. Disulfide bond contents increased dramatically after heat treatment and increased with decreasing $\mathrm{CN}$ :WP ratio $(P<0.05)$. The disulfide bond content reached a maximum of $27.78 \pm 1.24 \mu \mathrm{mol} / \mathrm{g}$ of protein at $95^{\circ} \mathrm{C}$ when the $\mathrm{CN}$ :WP ratio was 1:1.

The surface hydrophobicity $\left(\mathbf{S}_{0}\right)$ of samples was estimated using ANS as a fluorescence probe, with data shown in Table 4 . When the protein molecule was un-

Table 2. Rheological properties (means $\pm \mathrm{SD}$ ) of low-fat yogurts fortified with different casein to whey protein ratios

\begin{tabular}{|c|c|c|c|c|}
\hline Item & \multicolumn{4}{|c|}{ Casein to whey protein ratio } \\
\hline $\begin{array}{l}\text { Fermentation time }(\mathrm{min}) \\
\text { Gelation time }(\mathrm{min}) \\
\mathrm{pH} \text { at gelation } \\
\mathrm{G}^{\prime} \text { (storage modulus) at } \mathrm{pH} 4.6(\mathrm{~Pa})\end{array}$ & $\begin{aligned} 270.12 & \pm 2.31^{\mathrm{a}} \\
96.56 & \pm 4.62^{\mathrm{a}} \\
5.71 & \pm 0.01^{\mathrm{d}} \\
40.76 & \pm 5.23^{\mathrm{d}}\end{aligned}$ & $\begin{aligned} 262.22 & \pm 4.43^{\mathrm{b}} \\
88.42 & \pm 3.21^{\mathrm{b}} \\
5.78 & \pm 0.02^{\mathrm{c}} \\
51.12 & \pm 4.21^{\mathrm{c}}\end{aligned}$ & $\begin{aligned} 251.23 & \pm 5.82^{\mathrm{c}} \\
81.22 & \pm 3.11^{\mathrm{c}} \\
5.82 & \pm 0.01^{\mathrm{b}} \\
118.82 & \pm 13.23^{\mathrm{b}}\end{aligned}$ & $\begin{aligned} 240.15 & \pm 3.54^{\mathrm{d}} \\
76.12 & \pm 1.24^{\mathrm{d}} \\
5.88 & \pm 0.01^{\mathrm{a}} \\
206.35 & \pm 23.45^{\mathrm{a}}\end{aligned}$ \\
\hline
\end{tabular}

\footnotetext{
${ }^{\mathrm{a}-\mathrm{d}}$ Means within a row with different letters are significantly different $(P<0.05)$.
} 


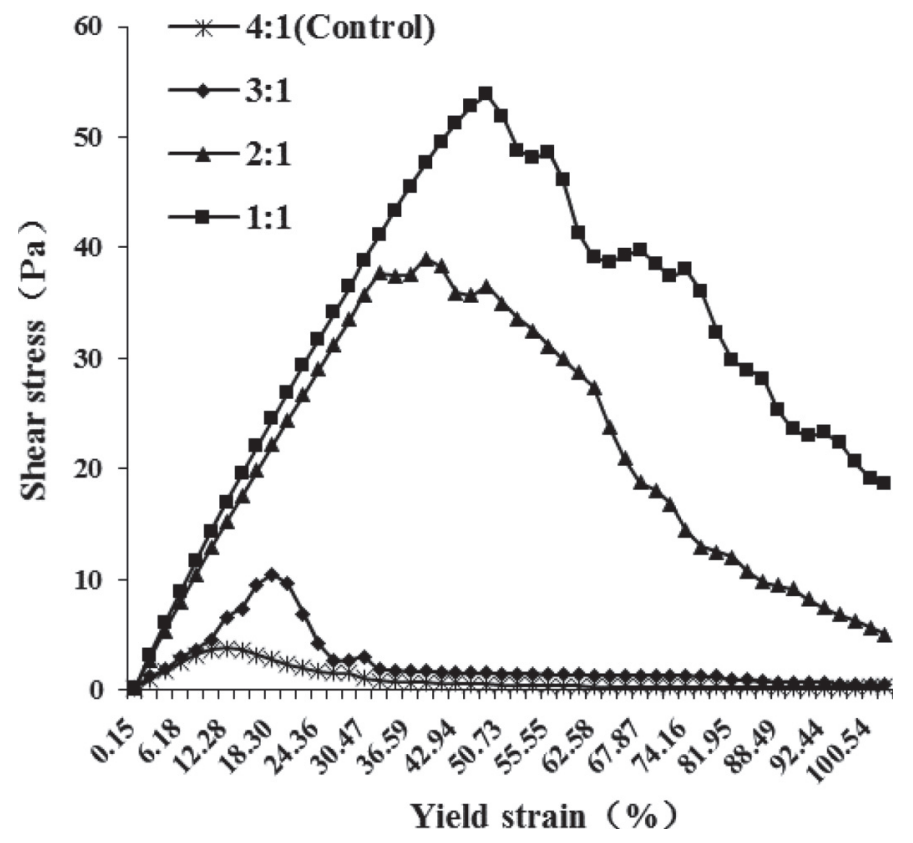

Figure 2. Shear stress as a function of strain applied deformation at a constant shear rate $(0.01 / \mathrm{s})$ for low-fat yogurts fortified with casein to whey protein ratios of 4:1 (control), 3:1, 2:1, and 1:1.

folded and the inner hydrophobic groups reacted with the ANS probe, an increase of fluorescence intensity was expected and the change of $\mathrm{S}_{0}$ values was observed. The $\mathrm{S}_{0}$ values of samples at $95^{\circ} \mathrm{C}$ increased significantly with decreasing $\mathrm{CN}$ :WP ratios $(P<0.05)$, whereas the opposite tendency $(P<0.05)$ of $\mathrm{S}_{0}$ values was observed at $25^{\circ} \mathrm{C}$. The $\mathrm{S}_{0}$ values at $95^{\circ} \mathrm{C}$ were higher than those at $25^{\circ} \mathrm{C}$. Thus, $\mathrm{S}_{0}$ was affected not only by heat intensity but also by $\mathrm{CN}$ :WP ratio.

\section{DISCUSSION}

The present study showed that when the CN:WP ratio was decreased to $2: 1$ and 1:1 with the addition of WPC80, the low-fat yogurt possessed higher values of $\mathrm{G}^{\prime}$ and yield stress and a more cross-linked network structure with smaller pores (Figures 1 to 3). These results were consistent with Kücükcetin (2008) and Puvanenthiran et al. (2002), who found that increased $\mathrm{G}^{\prime}$ and yield stress and a denser microstructure could be gained when the $\mathrm{CN}$ :WP ratio was decreased or the heating temperature was increased. This finding may be due to the shift in the amount of denatured whey proteins, which could be aggregated to provide linking protein agents (Lucey et al., 1999). These linking protein agents could interact with caseins to form whey protein-coated casein micelles. Increasing the amount of casein-whey complexes and connecting points could lead to increased branching and, consequently, gels with high $\mathrm{G}^{\prime}$ and firmness (Lucey et al., 1997). A higher volume fraction of whey proteins could lead to an increased number of covalent disulfide bonds that play a more important role than noncovalent bonds in gel structure during network formation (Krzeminski et al., 2011). Large particles could be formed by the addition of whey protein, which enables the gels to withstand by interparticle flexing forces and exhibit a high yield stress, without breaking the intraparticle cross-link bonds. A "shoulder" was observed for yogurts with CN:WP ratios of $4: 1,3: 1$, and $2: 1$, as shown in Figure 1, which might be due to the solubilization of colloidal casein phosphopeptides (CCP) from micelles, resulting in a transient loosening of the gel network (Anema, 2009). The CCP was solubilized when gelation occurred at a higher $\mathrm{pH}$, which weakened the internal structure of gel at $\mathrm{pH} 5.6$ to 5.4. The electric charges of proteins decreased as the $\mathrm{pH}$ continued to decrease, which made the proteins interact more strongly, and the $\mathrm{G}^{\prime}$ increased again at lower $\mathrm{pH}$. Therefore, the $\mathrm{G}^{\prime}$ shoulder was increased when the CCP level was increased in the sample with CN:WP ratios of $4: 1,3: 1$, and 2:1, which possessed higher casein content. This $\mathrm{G}^{\prime}$ shoulder phenomenon was also found by Andoyo et al. (2015) and Anema (2009).

Samples enriched with WPC80 also showed a short gelation time and a high gelation $\mathrm{pH}$ (Table 1). During yogurt fermentation, the buffering compounds in milk, such as soluble calcium phosphate and basic AA side chains of casein, become protonated and the micellar calcium phosphate dissolves in the serum phase (Gaucheron, 2005). A decreased concentration of buffering compounds from casein would decrease the buffering capacity and consequently accelerate the fermentation process. Moreover, the lower the $\mathrm{CN}$ :WP ratio, the greater the opportunity for whey to aggregate with $\kappa$-casein on the surface of micelles, which might also explain the shorter gelation time. However, Puvanenthiran et al. (2002) found that fermentation time increased when the CN:WP ratio was decreased by WPC40 addition, which was opposite to the behavior observed in the present study. These results demonstrate that different whey protein concentrates (WPC80 and WPC40) with different compositions might be the major factor affecting the length of fermentation. The present study showed that the $\mathrm{pH}$ value at gelation time was higher when the proportion of whey proteins in milk base increased, which was most probably due to the increased participation of denatured whey proteins that had generally higher isoelectric points $(\mathrm{pI} \approx 5.3$ for $\beta$-LG) than casein proteins. When the $\mathrm{pH}$ of the milk base was reduced and approached the isoelectric point of the unfolded and aggregated whey proteins, yogurt gels started to form (Jørgensen et al., 2015). 


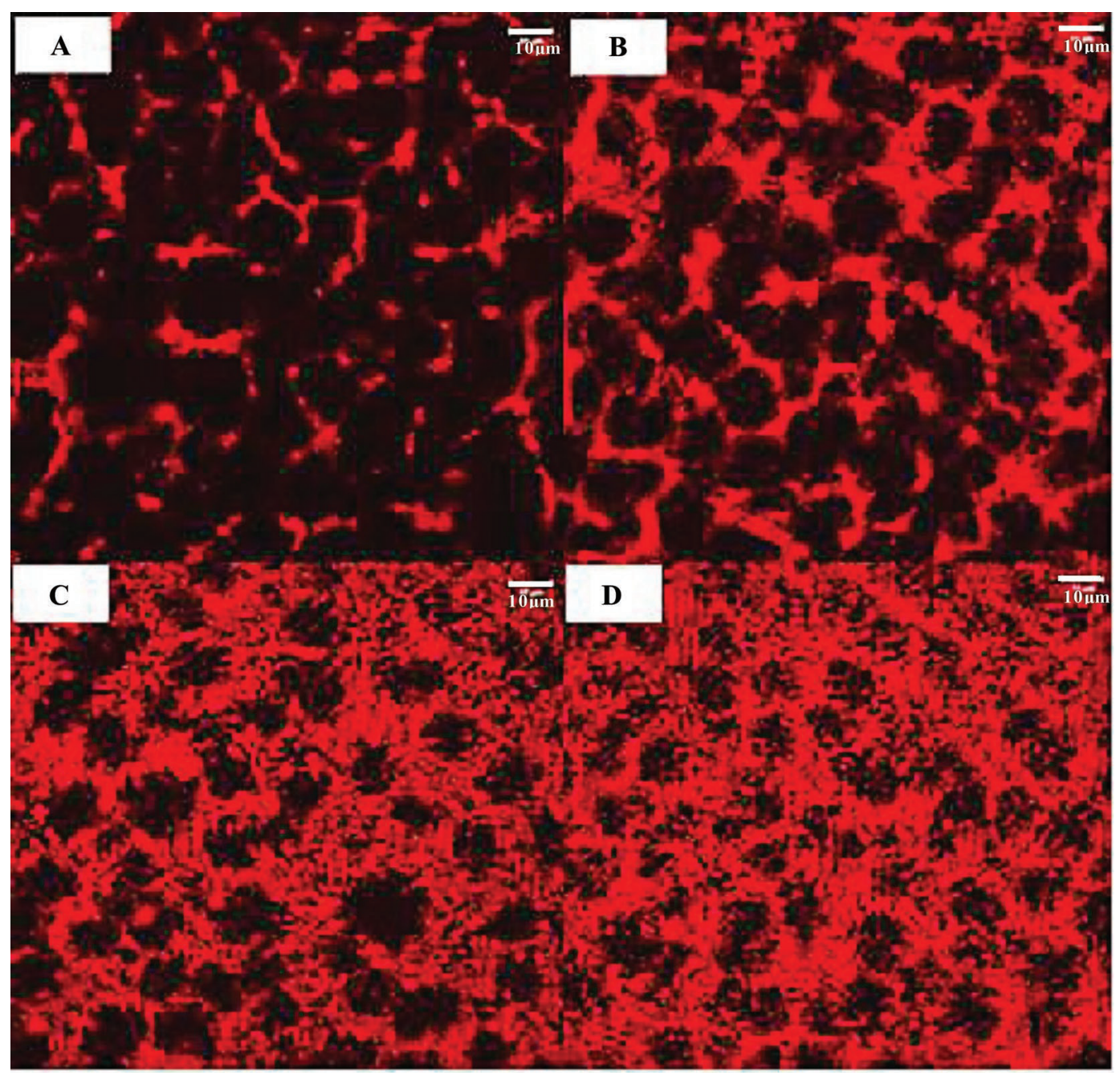

Figure 3. Electron micrographs of low-fat yogurts produced with casein to whey protein (CN:WP) ratios of 4:1 (Control, A), 3:1 (B), 2:1 (C), and 1:1 (D). As the CN:WP ratio decreased, the crosslinked network became denser and finer, and the pores became smaller, as shown in panels B, C, and D. The yogurt with a CN:WP of 1:1 (panel D) appeared the most homogeneous, with the smallest and most evenly distributed pores. Color version available online.

O'Kennedy and Kelly (2000) obtained a similar result and suggested that interactions between caseins and heat-denatured whey proteins could occur at $\mathrm{pH} 5.8$ to 6.2 . However, a lower gelation $\mathrm{pH}$ value of 5.25 was obtained by Lucey et al. (1998), which could be due to differences in heat treatment and starter culture.
Lucey et al. (1998) heated skim milk at $80^{\circ} \mathrm{C}$ for 30 min compared with $95^{\circ} \mathrm{C}$ for $5 \mathrm{~min}$ in the present study, which could affect the gelation properties and $\mathrm{pH}$ gelation value. In addition, it has been reported that EPS produced by starter culture could elevate the $\mathrm{pH}$ gelation value, which could be attributed to the EPS

Table 3. Disulfide bond content ( $\mu \mathrm{mol} / \mathrm{g}$ of protein; means $\pm \mathrm{SD}$ ) of unheated and heated milk protein samples with different casein to whey protein ratios

\begin{tabular}{|c|c|c|c|c|}
\hline \multirow[b]{2}{*}{ Treatment } & \multicolumn{4}{|c|}{ Casein to whey protein ratio } \\
\hline & 4:1 (Control) & $3: 1$ & $2: 1$ & $1: 1$ \\
\hline $\begin{array}{l}\text { Unheated }\left(25^{\circ} \mathrm{C}\right) \\
\text { Heated }\left(95^{\circ} \mathrm{C}\right)\end{array}$ & $\begin{array}{r}0.20 \pm 0.01^{\mathrm{d}, \mathrm{B}} \\
14.28 \pm 1.47^{\mathrm{d}, \mathrm{A}}\end{array}$ & $\begin{array}{r}0.23 \pm 0.01^{\mathrm{c}, \mathrm{B}} \\
20.07 \pm 1.51^{\mathrm{c}, \mathrm{A}}\end{array}$ & $\begin{array}{r}0.27 \pm 0.02^{\mathrm{b}, \mathrm{B}} \\
25.25 \pm 1.07^{\mathrm{b}, \mathrm{A}}\end{array}$ & $\begin{aligned} 0.33 & \pm 0.03^{\mathrm{a}, \mathrm{B}} \\
27.78 & \pm 1.24^{\mathrm{a}, \mathrm{A}}\end{aligned}$ \\
\hline
\end{tabular}


Table 4. Surface hydrophobicity $\left(\mathrm{S}_{0}\right.$, unitless; means $\left.\pm \mathrm{SD}\right)$ changes of unheated and heated milk protein samples with different casein to whey protein ratios

Casein to whey protein ratio

\begin{tabular}{|c|c|c|c|c|}
\hline Treatment & 4:1 (Control) & $3: 1$ & $2: 1$ & $1: 1$ \\
\hline$\overline{\text { Unheated }\left(25^{\circ} \mathrm{C}\right)}$ & $1,731.72 \pm 17.54^{\mathrm{a}, \mathrm{B}}$ & $1,567.23 \pm 18.38^{\mathrm{b}, \mathrm{B}}$ & $1,416.24 \pm 19.70^{\mathrm{c}, \mathrm{B}}$ & $1,351.32 \pm 17.64^{\mathrm{d}, \mathrm{B}}$ \\
\hline Heated $\left(95^{\circ} \mathrm{C}\right)$ & $2,178.01 \pm 28.31^{\mathrm{d}, \mathrm{A}}$ & $2,565.02 \pm 14.27^{\mathrm{c}, \mathrm{A}}$ & $2,720.05 \pm 12.08^{\mathrm{b}, \mathrm{A}}$ & $2,898.25 \pm 20.07^{\mathrm{a}, \mathrm{A}}$ \\
\hline
\end{tabular}

${ }^{\mathrm{a}-\mathrm{d}}$ Means within a row with different letters are significantly different $(P<0.05)$.

${ }^{\mathrm{A}, \mathrm{B}}$ Means within a column with different letters are significantly different $(P<0.05)$.

charge to facilitate the interaction between protein and polysaccharides, and EPS steric hindrance to induce casein micelles to interact with each other at higher $\mathrm{pH}$ (Mende et al., 2013).

In addition, the TS content of the milk base (Table 1) decreased with WPC addition, which meant the contents of lactose and minerals in the milk base decreased with constant total protein concentration. However, yogurt properties still improved with the decrease in TS contents, so this is likely not an important factor affecting yogurt properties.

With an increase in CN:WP ratio, more hydrophobic groups were exposed and more disulfide bonds were produced after heat treatment, as shown in Tables 3 and 4 , which was consistent with the result of Nicolai et al. (2011). Whey proteins unfold and expose inner hydrophobic groups when heated at temperatures above $65^{\circ} \mathrm{C}$ (Croguennec et al., 2004) and tend to interact with themselves or $\kappa$-casein to form heat-induced polymers (Jang and Swaisgood, 1990). Denatured $\beta$-LG molecules might be involved in thiol oxidation reactions and in intermolecular interchange reactions at higher temperatures (Sava et al., 2005). Therefore, a high concentration of whey proteins could provide large amounts of free thiol groups of $\beta-\mathrm{LG}$ to form disulfide bonds, and high temperature could induce $\beta$-LG structure changes, which are mainly responsible for the altered rheological properties and structures of low-fat acid gels; $\alpha$-LA is significantly involved in formation these complexes as well (Law et al., 1994; Noh et al., 1989).

The aggregation of protein could be hampered and rheological properties could become weak if $\mathrm{CN}$ :WP ratios increase, because the excess casein micelles that were not covered adequately with whey protein might not be aggregated by non-disulfide bonds or not aggregated. Low heating intensity could increase formation of polar bonds between proteins but weaken the hydrophobic interaction in milk with a high portion of whey protein. Appropriate CN:WP ratio in milk samples and heat treatment are required to provide sufficient disulfide bonds for casein-whey protein aggregates and whey protein aggregates, which could be key to gelation.

\section{CONCLUSIONS}

Changing CN:WP ratio combined with a constant total protein content could dramatically affect the physical and rheological properties of low-fat yogurt. As the CN:WP ratio decreased, yield stress and $\mathrm{G}^{\prime}$ of the obtained yogurt increased, fermentation time was decreased, and microstructure became more homogeneous. When the $\mathrm{CN}: \mathrm{WP}$ ratio was $2: 1$ or $1: 1$, the yogurt gel possessed better rheological properties with the highest $\mathrm{G}^{\prime}$ value and yield point, the shortest gelation period, and a compact network with more disulfide bonds and hydrophobic interactions. Therefore, the $\mathrm{CN}$ :WP ratio can be optimized to improve the quality of low-fat yogurt in practical manufacture. In addition, proper heat treatment, which affects the denaturation and interaction of milk proteins, was an important contributor to gel formation of low-fat yogurt.

\section{ACKNOWLEDGMENTS}

We are grateful for the financial support for this work by the National Dairy Industry Technology SystemBeijing Innovation Team (China; NDITS-BIT), National Natural Science Foundation of China (31371753), and National Science and Technology Projects (China; 2013BAD18B12-05). All authors have read and approved the final manuscript.

\section{REFERENCES}

Akalin, A. S., G. Unal, S. Gonc, and S. Fenderya. 2008. Effects of whey protein concentrate and fructooligosaccharide on the rheological and sensory properties of reduced-fat probiotic yoghurt. Milchwissenschaft 63:171-174.

Alizadeh-Pasdar, N., and E. C. Li-Chan. 2000. Comparison of protein surface hydrophobicity measured at various $\mathrm{pH}$ values using three different fluorescent probes. J. Agric. Food Chem. 48:328-334.

Andoyo, R., F. Guyomarc'h, A. Burel, and M. H. Famelart. 2015. Spatial arrangement of casein micelles and whey protein aggregate in acid gels: Insight on mechanisms. Food Hydrocoll. 51:118-128.

Anema, S. G. 2009. Role of colloidal calcium phosphate in the acid gelation properties of heated skim milk. Food Chem. 114:161-167.

Beveridge, T., S. J. Toma, and S. Nakai. 1974. Determination of SHand SS- groups in some food proteins using Ellman's reagent. J. Food Sci. 39:49-51. 
Bhullar, Y. S., M. A. Uddin, and N. P. Shah. 2002. Effects of ingredients supplementation on textural characteristics and microstructure of yoghurt. Milchwissenschaft 57:329-332.

Croguennec, T., B. T. O. Kennedy, and R. Mehra. 2004. Heat-induced denaturation/aggregation of $\beta$-lactoglobulin A and B: Kinetics of the first intermediates formed. Int. Dairy J. 14:399-409.

Damin, M. R., M. R. Alcântara, A. P. Nunes, and M. N. Oliveira. 2009. Effects of milk supplementation with skim milk powder, whey protein concentrate and sodium caseinate on acidification kinetics, rheological properties and structure of nonfat stirred yogurt. LWT-Food Sci. Technol. 42:1744-1750.

Ellman, G. L. 1959. Tissue sulfhydryl groups. Arch. Biochem. Biophys. 82:70-77.

Gaucheron, F. 2005. The minerals of milk. Reprod. Nutr. Dev. 45:473483.

González-Martınez, C., M. Becerra, M. Cháfer, A. Albors, J. M. Carot, and A. Chiralt. 2002. Influence of substituting milk powder for whey powder on yoghurt quality. Trends Food Sci. Technol. 13:334-340.

Graveland-Bikker, J. F., and S. G. Anema. 2003. Effect of individual whey proteins on the rheological properties of acid gels prepared from heated skim milk. Int. Dairy J. 13:401-408.

Haque, Z., and J. E. Kinsella. 1988. Interaction between heated $\kappa$-casein and $\beta$-lactoglobulin: predominance of hydrophobic interactions in the initial stages of complex formation. J. Dairy Res. $55: 67-80$

Hinrichs, J. 2001. Incorporation of whey proteins in cheese. Int. Dairy J. 11:495-503.

Houzé, G., E. Cases, B. Colas, and P. Cayot. 2005. Viscoelastic properties of acid milk gel as affected by fat nature at low level. Int. Dairy J. 15:1006-1016.

Jang, H. D., and H. E. Swaisgood. 1990. Disulfide bond formation between thermally denatured $\beta$-lactoglobulin and $\kappa$-casein in casein micelles. J. Dairy Sci. 73:900-904.

Jørgensen, C. E., R. K. Abrahamsen, E. O. Rukke, A. G. Johansen, R. B. Schüller, and S. B. Skeie. 2015. Improving the structure and rheology of high protein, low fat yoghurt with undenatured whey proteins. Int. Dairy J. 47:6-18.

Kelly, P. M., and B. T. O'Kennedy. 2001. The effect of casein/whey protein ratio and minerals on the rheology of fresh cheese gels using a model system. Int. Dairy J. 11:525-532.

Krzeminski, A., K. Grosshable, and J. Hinrichs. 2011. Structural properties of stirred yoghurt as influenced by whey proteins. LWTFood Sci Technol. 44:2134-2140.

Kücükcetin, A. 2008. Effect of heat treatment and casein to whey protein ratio of skim milk on graininess and roughness of stirred yoghurt. Food Res. Int. 41:165-171.

Law, A., J. M. Banks, D. S. Horne, J. Leaver, and I. G. West. 1994. Denaturation of the whey proteins in heated milk and their incorporation into Cheddar cheese. Milchwissenschaft 49:63-67.

Lee, W. J., and J. A. Lucey. 2004. Structure and physical properties of yogurt gels: Effect of inoculation rate and incubation temperature. J. Dairy Sci. 87:3153-3164.

Lucey, J. A. 2002. Formation and physical properties of milk protein gels. J. Dairy Sci. 85:281-294.
Lucey, J. A., P. A. Munro, and H. Singh. 1999. Effects of heat treatment and whey protein addition on the rheological properties and structure of acid skim milk gels. Int. Dairy J. 9:275-279.

Lucey, J. A., and H. Singh. 1997. Formation and physical properties of acid milk gels: A review. Food Res. Int. 30:529-542.

Lucey, J. A., C. T. Teo, P. A. Munro, and H. Singh. 1998. Microstructure, permeability and appearance of acid gels made from heated skim milk. Food Hydrocoll. 12:159-165.

Lucey, J. A., T. Van Vliet, K. Grolle, T. Geurts, and P. Walstra. 1997. Properties of acid casein gels made by acidification with glucono- $\delta$ lactone. 1. Rheological properties. Int. Dairy J. 7:381-388.

Mende, S., M. Peter, K. Bartels, H. Rohm, and D. Jaros. 2013. Addition of purified exopolysaccharide isolates from $S$. thermophilus to milk and their impact on the rheology of acid gels. Food Hydrocoll. 32:178-185.

Mulvihill, D. M., and M. B. Grufferty. 1995. Effect of thermal processing on the coagulability of milk by acid. Pages $188-205$ in Lactation: Heat-Induced Changes in Milk. 2nd ed. P. F. Fox, ed. International Dairy Federation, Brussels, Belgium.

Nicolai, T. M. Britten, and C. Schmitt. 2011. B-Lactoglobulin and WPI aggregates: Formation, structure and applications. Food Hydrocoll. 25:1945-1962.

Noh, B., T. Richardson, and L. K. Creamer. 1989. Radiolabelling study of the heat-induced interactions between $\alpha$-lactalbumin, $\beta$-lactoglobulin and k-casein in milk and in buffer solutions. J. Food Sci. 54:889-893.

O'Kennedy, B. T., and P. M. Kelly. 2000. Evaluation of milk protein interactions during acid gelation using a simulated yoghurt model. Milchwissenschaft 55:187-190.

Puvanenthiran, A., R. Williams, and M. A. Augustin. 2002. Structure and visco-elastic properties of set yoghurt with altered casein to whey protein ratios. Int. Dairy J. 12:383-391.

Remeuf, F., S. Mohammed, I. Sodini, and J. P. Tissier. 2003. Preliminary observations on the effects of milk fortification and heating on microstructure and physical properties of stirred yogurt. Int. Dairy J. 13:773-782.

Sava, N., I. Van der Plancken, W. Claeys, and M. Hendrickx. 2005. The kinetics of heat-induced structural changes of $\beta$-lactoglobulin. J. Dairy Sci. 88:1646-1653.

Singh, B. R., and K. Myhr. 1998. Cadmium uptake by barley as affected by Cd sources and pH levels. Geoderma 84:185-194.

Smits, P., and J. H. V. Brouwershaven. 1980. Heat-induced association of $\beta$-lactoglobulin and casein micelles. J. Dairy Res. 47:313-325.

Sodini, I., F. Remeuf, S. Haddad, and G. Corrieu. 2004. The relative effect of milk base, starter, and process on yogurt texture: a review. Crit. Rev. Food Sci. Nutr. 44:113-137.

Tomaschunas, M., J. Hinrichs, E. Köhn, and M. Busch-Stockfisch. 2012. Effects of casein-to-whey protein ratio, fat and protein content on sensory properties of stirred yoghurt. Int. Dairy J. 26:3135.

Van Camp, J., W. Messens, J. Clément, and A. Huyghebaert. 1997. Influence of $\mathrm{pH}$ and sodium chloride on the high pressure-induced gel formation of a whey protein concentrate. Food Chem. 60:417-424. 